\title{
In Situ Visualization of PD-L1-Specific Glycosylation on Tissue Sections
}

Mengjiao Huang ${ }^{\dagger} \S$, Lin Zhu ${ }^{\dagger}$, Siyin Kang ${ }^{\dagger}$, Fude Chen ${ }^{\dagger}$, Xinyu Wei ${ }^{\dagger}$, Liyuan Lin ${ }^{\ddagger}$, Xiaofeng Chen ${ }^{\dagger}$, Wei Wang ${ }^{\ddagger}$, Zhi Zhu ${ }^{\dagger}$, Chaoyong Yang ${ }^{\dagger, \ddagger}$, Yanling Song *†

$\dagger$ The MOE Key Laboratory of Spectrochemical Analysis and Instrumentation, Collaborative Innovation Center of Chemistry for Energy Materials, State Key Laboratory of Physical Chemistry of Solid Surfaces, Department of Chemical Biology, College of Chemistry and Chemical Engineering, Xiamen University, Xiamen, 361005, China

† Institute of Molecular Medicine, Renji Hospital, Shanghai Jiao Tong University School of Medicine, Shanghai, 200127, China

$\S$ State Key Laboratory for Chemistry and Molecular Engineering of Medicinal Resources, College of Chemistry and Pharmacy, Guangxi Normal University, Guilin, Guangxi 541004, China 


\section{Experimental Procedures}

\subsection{Buffer and Reagents}

Binding buffer $(\mathrm{pH}=7.4$, PBS containing $0.55 \mathrm{mM} \mathrm{MgCl}$ ) and HEPES buffer $(\mathrm{pH}=7.4$, including $50 \mathrm{mM}$ HEPES, $140 \mathrm{mM} \mathrm{NaCl}, 2.5 \mathrm{mM} \mathrm{MgCl}$, $1 \mathrm{mM} \mathrm{CaCl}$ ) were used in flow cytometric analysis and confocal imaging. HEPES buffer was used for binding and imaging assays of cells with Con A. Binding buffer was used for binding and imaging assays of cells with MJ5C aptamer. MJ5C aptamer or control sequence used in flow cytometric analysis (Cy5-labeled) and confocal imaging (FAM-labeled) were synthesized by Sangon Biotech (Shanghai, China). Concanavalin A (Con A) was obtained from Sigma (C7642-2 MG and L7647-25 MG). Cy3 conjugated Con A was used for flow cytometric analysis (cells) and confocal imaging (cells and tissues). FITC conjugated Con A was used for flow cytometric analysis of cells after Epidermal Growth Factor human (EGF, Sigma, E9644) induction. FITC-labeled PD-L1 Antibody (PD-L1/2746) was obtained from Novus (NBP2-80491F), which was used for confocal imaging (tissues). Deionized water (Milli-Q water purification system) was used to prepare all buffers and samples.

\subsection{Cell Lines and Cell Culture}

Human colorectal cancer cell HCT 116 and chronic myelogenous leukemia cell K562 were purchased from American Type Culture Collection. The HCT 116 cell line was cultured in RPMI 1640 medium. K562 cell line was cultured in a DMEM medium. Two cell lines were cultured in a medium supplemented with $10 \%$ fetal bovine serum and $100 \mathrm{U} / \mathrm{mL}$ penicillin-streptomycin at $37^{\circ} \mathrm{C}$ in a humidified atmosphere with $5 \% \mathrm{CO}_{2}$.

\subsection{Cell Deglycosylation and Fluorescence Detection}

To investigate how the glycan structure of PD-L1 hinders its aptamer/antibody-based recognition, PD-L1 positive HCT 116 cells were pretreated with or without PNGase F, and the HCT 116 cells were pretreated with PNGase $\mathrm{F}$ for cell deglycosylation. The cell deglycosylation was performed as described previously. ${ }^{1}$ First, HCT 116 cells seeded in the 96-well plates were fixed with $4 \%$ paraformaldehyde. Then, the fixed cells were denatured with glycoprotein denaturing buffer and deglycosylated with PNGase $F(5 \%)$. Next, the cells were permeabilized using $0.5 \%$ Triton X-100 and blocked using $5 \%$ bovine serum albumin (BSA). Then, the cells were washed with PBS, and incubated with FAM-labeled PD-L1 aptamer in binding buffer or APC-labeled PD-L1 antibody (BioLegend, Clone 29E2A3) in PBS at $4^{\circ} \mathrm{C}$ for $12 \mathrm{~h}$ in the dark. Finally, the cells were washed 3 times and analyzed with a microplate reader (Molecular Devices, SpectraMax iD5) to obtain the fluorescence value.

\subsection{Flow Cytometric Analysis.}

To characterize the interference between the PD-L1 aptamer and Con A in simultaneously staining, PD-L1 positive cells HCT 116 or negative cells K562 were incubated with single Cy5-labeled PD-L1 aptamer (200 nM) or control sequence in binding buffer at room temperature for 30 min in the dark. Using a similar strategy, PD-L1 positive cells HCT 116 or negative cells K562 were incubated with single Cy3-labeled Con A $(5 \mu \mathrm{g} / \mathrm{mL})$ or control protein in HEPES buffer in an Ice bath for $5 \mathrm{~min}$, respectively. Besides, for PD-L1 aptamer and Con A dualstaining, after the incubation of HCT 116 or K562 cells with PD-L1 aptamer at room temperature for $25 \mathrm{~min}$, then Con A was added to the mixture and incubated on ice bath for $5 \mathrm{~min}$. After washing, the BD flow cytometer was used to measure the fluorescence signals of the stained cells. Control sequence and control protein were used as control.

To characterize the binding performance of PD-L1 aptamer or Con A against HCT 116 cells treated with different doses of EGF ( 0 and $25 \mathrm{ng} / \mathrm{mL}$ ), a similar strategy was used. EGF-treated HCT 116 cells were incubated with single FAM-labeled PD-L1 aptamer $(200 \mathrm{nM})$ in binding buffer at room temperature for $30 \mathrm{~min}$. A control sequence was used as a control. EGF-treated HCT 116 cells were incubated with single FITC-labeled Con A ( $5 \mu \mathrm{g} / \mathrm{mL}, \mathrm{C} 7642-2 \mathrm{MG})$ in HEPES buffer in an ice bath for $5 \mathrm{~min}$. A control protein was used as a control. After incubation, the stained cells were washed twice and detected using BD flow cytometry.

\subsection{EGF Signaling Enhanced PD-L1 Expression}

First, HCT 116 cells were treated in a serum-free medium overnight and then treated with different doses of EGF ( 0 and $25 \mathrm{ng} / \mathrm{mL}$ ) overnight. Then, they were directly used for different analyses. For flow cytometric analysis and confocal imaging of FRET analysis, the steps were as 
described above (1.4 Flow Cytometric Analysis and Confocal Imaging and FRET Measurement).

For Western blotting analysis, HCT 116 cells were first lysed using RIPA buffer (with protease inhibitor). Then the PD-L1 antibody (Cell Signaling Technology, Cat\#13684) was used for analysis, and tubulin (Cell Signaling Technology, Cat\#2148) was used as a control.

\section{Results and Discussion}

\section{PD-L1 Negative cell}

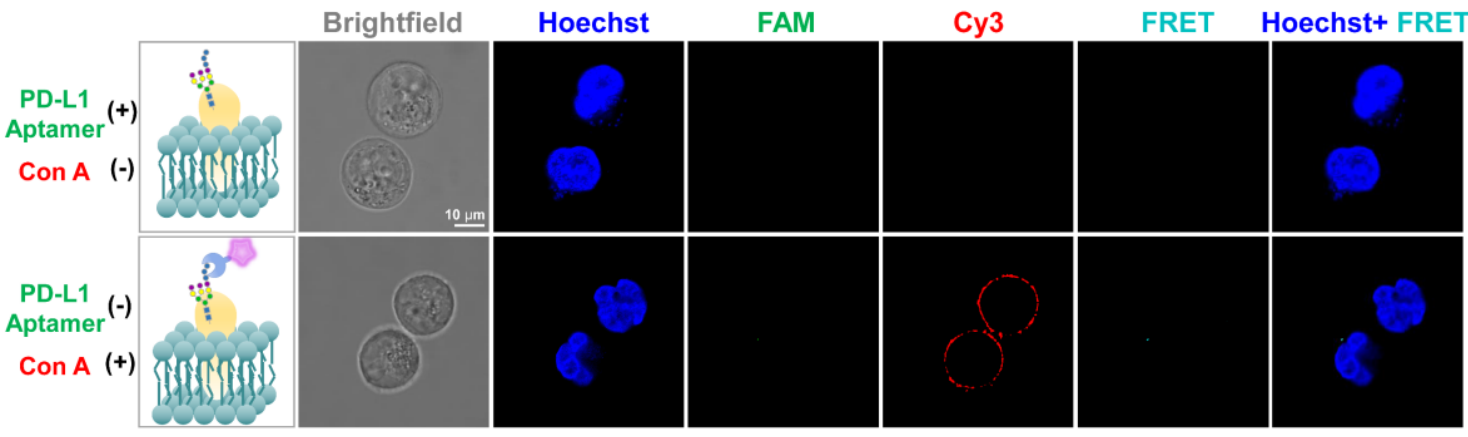

Figure S1. PD-L1 negative K562 cells were single-stained with PD-L1 aptamer or Con A. Nuclei: Hoechst 33342 (blue), PD-L1 aptamer: FAM (green), Con A: Cy3 (red), FRET: (cyan-blue). Scale bar equals $10 \mu \mathrm{m}$.

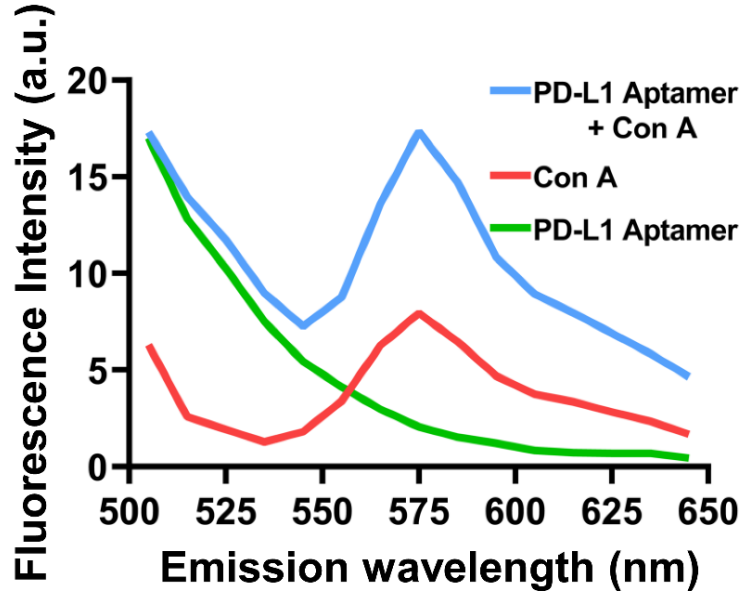

Figure S2. Emission spectra of FRET signals obtained on HCT 116 cell surfaces when excited at 488 $\mathrm{nm}$. 

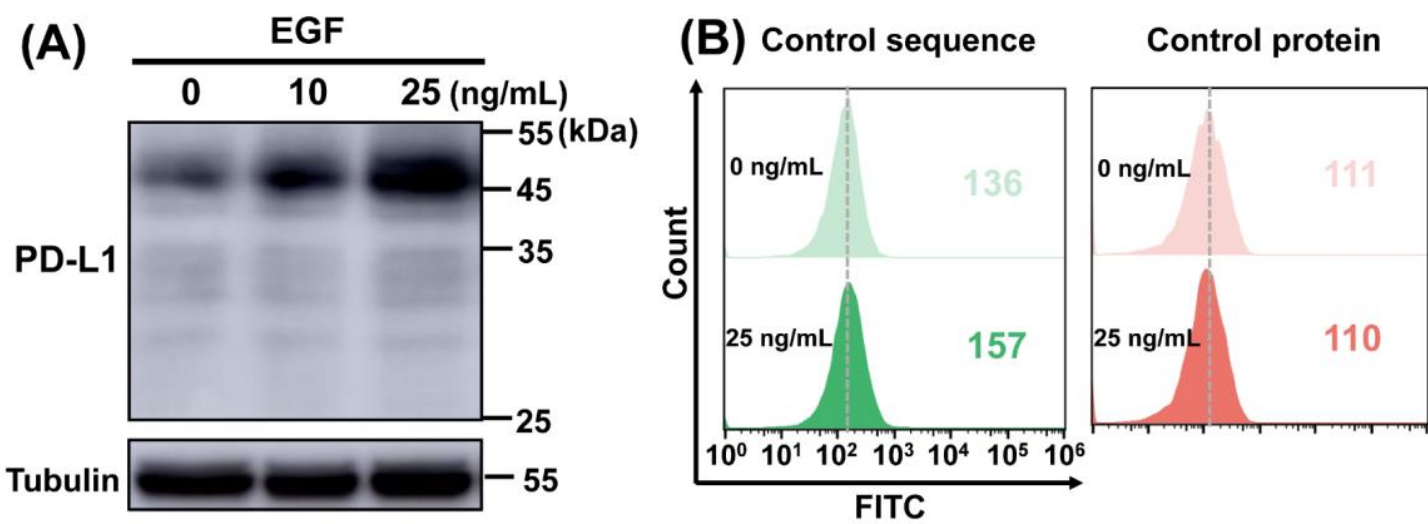

Figure S3. (A) Expression of PD-L1 protein upregulated by EGF signaling and analyzed by Western blotting analysis. (B) Flow cytometric analysis of the binding performance of control sequence and control protein against HCT 116 cells treated with different doses of EGF ( 0 and $25 \mathrm{ng} / \mathrm{mL}$ ).
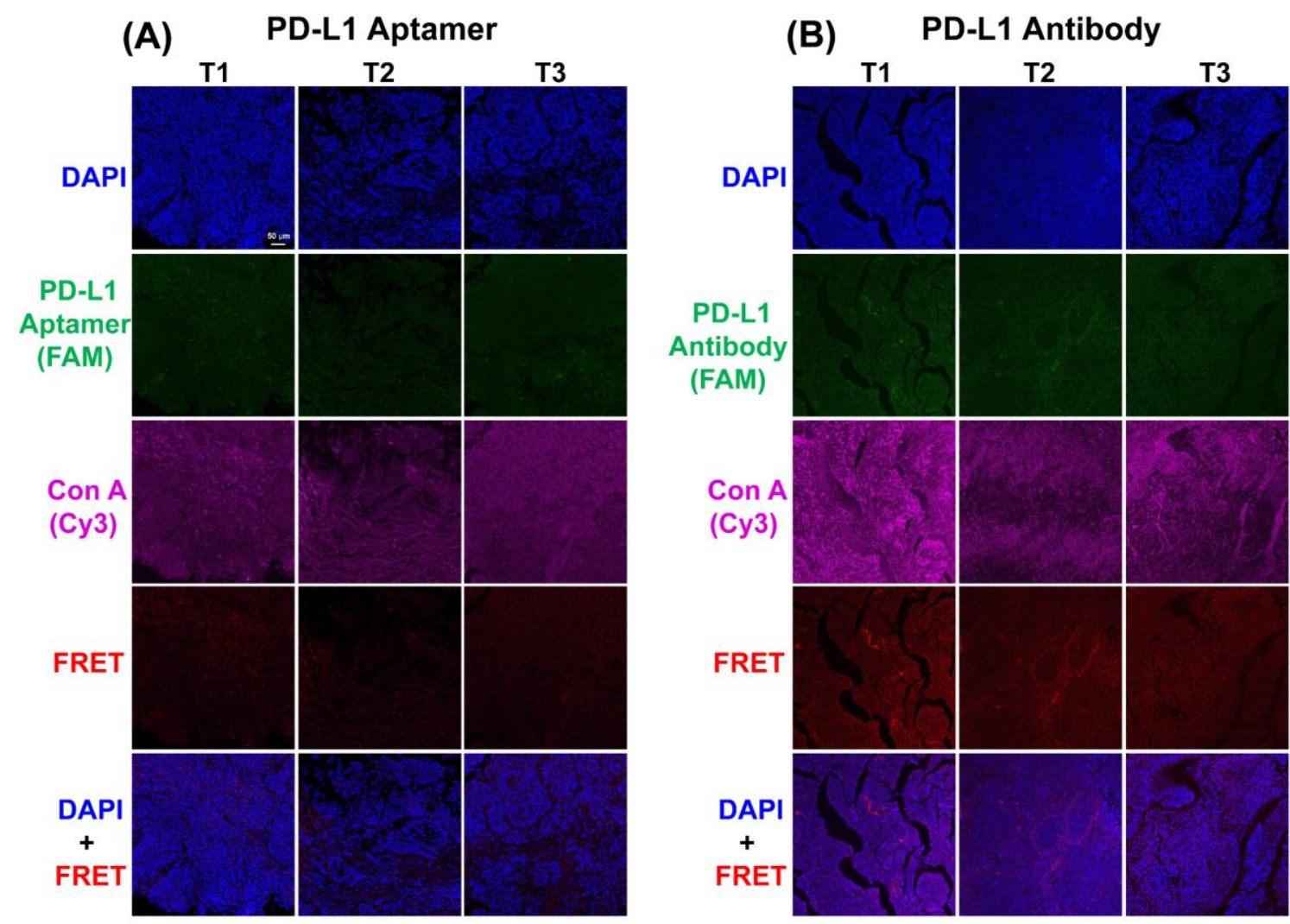

Figure S4. $(A)$ and $(B)$ FRET imaging of PD-L1 negative tissues dual-stained with PD-L1 aptamer and Con A or PD-L1 antibody and Con A, respectively. Nuclei: DAPI ( blue), PD-L1 aptamer and PD-L1 antibody: FAM (green), Con A: Cy3 (purple), FRET: (red). Scale bar equals $50 \mu \mathrm{m}$. 
Table S1. Clinical tissue information

\begin{tabular}{|c|c|c|c|c|c|c|c|c|}
\hline $\begin{array}{l}\text { Serial } \\
\text { Number }\end{array}$ & Gender & Year & Clinical Investigations & $\begin{array}{c}\text { Organ/ } \\
\text { Anatomic Site }\end{array}$ & $\begin{array}{c}\text { TNM } \\
\text { Staging }\end{array}$ & $\begin{array}{l}\text { Tumor } \\
\text { stage }\end{array}$ & Therapy & $\begin{array}{l}\text { Treatment } \\
\text { effect }\end{array}$ \\
\hline T1 & Male & 76 & Lymphoepithelial cyst & Throat & TxN1M0 & III & $\begin{array}{l}\text { PD-1 antibody, } \\
\text { Toripalimab }\end{array}$ & Metastasis \\
\hline T2 & Male & 65 & $\begin{array}{c}\text { Well differentiated } \\
\text { squamous cell carcinoma }\end{array}$ & Throat & T3N1M0 & III & $\begin{array}{l}\text { PD-1 antibody, } \\
\text { Toripalimab }\end{array}$ & $\begin{array}{l}\text { Lymph node } \\
\text { metastasis }\end{array}$ \\
\hline T3 & Male & 57 & $\begin{array}{l}\text { Poorly differentiated } \\
\text { pancreatic cancer }\end{array}$ & Pancreas & T2NOMO & IB & $\begin{array}{c}\text { PD-L1 } \\
\text { antibody, } \\
\text { Atezolizumab }\end{array}$ & $\begin{array}{c}\text { Swollen } \\
\text { lymph nodes }\end{array}$ \\
\hline T4 & Male & 44 & $\begin{array}{l}\text { Undifferentiated non- } \\
\text { keratinizing carcinoma }\end{array}$ & Nasopharyngeal & T1N1M0 & III & $\begin{array}{l}\text { PD-1 antibody, } \\
\text { Toripalimab }\end{array}$ & No progress \\
\hline T5 & Male & 52 & Malignant melanoma & Nasopharyngeal & T4aNOMO & IVA & $\begin{array}{l}\text { PD-1 antibody, } \\
\text { Toripalimab }\end{array}$ & No progress \\
\hline T6 & Male & 72 & $\begin{array}{l}\text { Moderately differentiated } \\
\text { squamous cell carcinoma }\end{array}$ & Tonsil & T2N1M0 & III & $\begin{array}{c}\text { PD-L1 } \\
\text { antibody, } \\
\text { Durvalumab }\end{array}$ & No progress \\
\hline T7 & Female & 36 & Malignant tumor & Nasopharyngeal & T1N1M0 & III & $\begin{array}{c}\text { PD-L1 } \\
\text { antibody, } \\
\text { Durvalumab }\end{array}$ & $\begin{array}{l}\text { Lymph } \\
\text { nodes } \\
\text { shrunken }\end{array}$ \\
\hline
\end{tabular}

Table S2. Sequences in this work

\begin{tabular}{cc}
\hline Name & Sequence (5'-3') \\
\hline PD-L1 & TACAGGTTCTGGGGGGTGGGTGGGGAACCTGTT \\
Aptamer & \\
Control & ATTACCTCTAAATCACTGCTCTGTAACATGGTCGCGCTAGG \\
\hline
\end{tabular}

\section{References}

(1) Huang, M.; Yang, J.; Wang, T.; Song, J.; Xia, J.; Wu, L.; Wang, W.; Wu, Q.; Zhu, Z.; Song, Y.; Yang, C., Homogeneous, Low-volume, Efficient, and Sensitive Quantitation of Circulating Exosomal PD-L1 for Cancer Diagnosis and Immunotherapy Response Prediction. Angew. Chem. Int. Ed. 2020, 59, 4800-4805. 